\title{
Tito's Yugoslavia, Stories Untold. Volume 1 and 2
}

Gorana Ognjenović \& Jasna Jozelić (red.)

New York: Palgrave Macillan 2016

Volume 1: 242 sider. ISBN 9781137597434

Volume 2: 265 sider. ISBN 9781137597472

Anmeldt af Tea Sindbæk Andersen [Adjunkt, Institut for Tværkulturelle og Regionale Studier, Københavns Universitet, nxr333@hum.ku.dk]

Historien om det socialistiske Jugoslavien har levet en omstridt tilværelse siden 1990, da det jugoslaviske kommunistforbund brød sammen, efterfulgt i 1991 af opløsningen af den jugoslaviske føderation og krigene i Slovenien, Kroatien, Bosnien og Kosovo. Historieskrivningen i de nye, formelt demokratiske post-jugoslaviske nationalstater fokuserede på nationale fortællinger, ofte ud fra et offerperspektiv. Kommunismens fald muliggjorde desuden at historikere og massemedier kunne udforske kommunisternes egne forbrydelser, også dem, der blev fortiet i den kommunistiske periode. Erkendelsen af kommunismens omfattende forbrydelser medførte en voldsom delegitimering af den kommunistiske æras historieskrivning, og sammen med de nye nationale dagsordener skabte dette en kaotisk historieskrivningskultur, hvor »alle kunne skrive deres egen historie«, som Gorana Ognjenović og Jasna Jozelić skriver i Tito's Yugoslavia, Stories Untold (bind 1, s. 233).

Fremstillinger af jugoslavisk historie publiceret af forfattere uden for Jugoslaviens efterfølgerstater har til gengæld primært haft til hensigt at forklare, hvorfor Jugoslavien brød sammen og følge de mange kriser og svaghedstegn i den jugoslaviske stats historie, som bidrog til føderationens ødelæggelse i 1991. Nu, 25 år efter Jugoslaviens sammenbrud, er det imidlertid igen relevant at kaste et blik på Titos Jugoslavien i sin egen ret. Masser af ny forskning om aspekter af den titoistiske stat er produceret både i og udenfor de tidligere jugoslaviske stater, og det er et meget velkomment projekt at forsøge at samle nogle af disse perspektiver. Det er netop hvad Gorana Ognjenović og Jasna Jozelić har bestræbt sig på i deres to-binds antologi om Titos Jugoslavien.

Tito's Yugoslavia, Stories Untold indeholder en samling af nye forskningsbaserede undersøgelser af det socialistiske Jugoslaviens historie under og efter Tito. Et væsentligt mål for de to redaktører er at komme videre fra, hvad de ser som en forsimplet diskussion om hvorvidt Titos Jugoslavien var "totalitært eller socialistisk" (bind 1, s. 233). Tito's Yugoslavia, Stories Untold forsøger i stedet at sætte fokus på de komplekse forandringsprocesser, som formede Jugoslavien fra 1945 til 1990. 
Første bind, Revolutionary Totalitarianism, Pragmatic Socialism, Transition, beskæftiger sig med opbygningen og udviklingen af den socialistiske stat og med arven efter Anden Verdenskrig. Kapitlernes emner dækker et bredt spektrum af tematikker fra udenrigspolitik til behandling af krigsfanger. Blandt de måske mest interessante er Tvrtko Jakovinas indholdsrige og elegante oversigt over udviklingen i forholdet mellem det socialistiske Jugoslavien og USA, som ifølge forfatteren var vigtigere end selv forholdet til USSR (s. 101) og Zachary Irwins koncise indføring i Jugoslaviens rolle i den alliancefrie bevægelse.

Den socialistiske stats politiske transformationer behandles først i Zdenko Radelić' detaljerede kapitel om kommunistpartiets magtovertagelse og elimineringen af politisk opposition i Kroatien, og siden af Hrvoje Klasić i kapitlet om de politiske protester i 1968. Klasić fremhæver her de afgørende tendenser til decentralisering af politisk og økonomisk magt i Jugoslavien fra det føderale centrum til delrepublikkerne. Endelig behandles nogle af de forfærdeligste aspekter af Jugoslaviens Anden Verdenskrig: Nataša Mataušić' kapitel behandler den dybt fascinerende historie om en mageløs aktion, ledet af Diana Budisavljević, for at redde børn fra de uhyrlige forhold i det kroatiske fascistiske regimes koncentrationslejre. Gorana Ognjenović' kapitel udforsker historien om jugoslaviske krigsfanger, som blev deporteret fra serbiske lejre til nazistiske arbejdslejre i Norge.

Andet bind, Titoism, Self-Determination, Nationalism, Cultural Memory omhandler dels de ideologiske, økonomiske og kulturelle transitioner, der kendetegnede Titos Jugoslavien i den senere periode, og dels Titoismens efterliv i form af kollektiv erindring og nostalgi. I bindets første kapitel giver Ognjenović, Mataušić og Jozelić et overblik over den jugoslaviske socialismes væsentligste ideologiske udvikling og fremhæver den accelererede modernisering, der kendetegnede det kommunistiske projekt, ikke mindst hvad angår uddannelse, levestandard og sundhedsniveau. Intellektuel og ideologisk udvikling er emnet både for Albert Bings essay om vanskelighederne med at forbinde titoismen med "national selvbestemmelse" og for Latinka Perović' fascinerende kapitel om forholdet mellem Tito og Dobrica Ćosić, partisanveteran og kommunistisk forfatter, der forlod partiet i slutningen af 1960'erne for at blive nationalistisk intellektuel og senere også politiker.

Kollektiv erindring under og efter kommunismen er et af omdrejningspunkterne for de resterende kapitler. Jurica Pavičić beskriver hvordan film om partisanernes kamp under Anden Verdenskrig udviklede sig som genre og tiente til at promovere statens væsentligste ideologiske byggesten, nemlig partisanmyten, socialismen og sloganet "broderskab og enhed". Nevena Škrbić Alempijević og Kirsti Mathiesen Hjemdahl analyserer fejringer i Titos fødested, landsbyen Kumrovec, som under kommunismen blev indrettet som frilandsmuseum og mindepark, og diskuterer den betydning, landsbyen siden har fået som erindringssted og fokuspunkt for nostalgi efter det tidligere Jugoslavien. Mitja Velikonja diskuterer originalt og fordomsløst brugen af ægte eller falsk "Yugo-vintage tøj« i 2010'erne og konkluderer, at bærerne bruger historiske symboler til at udtrykke en stærk ideologisk modstand mod dagens 


\section{6 | TEA SINDBÆK ANDERSEN}

politiske orden, særligt neoliberalisme og nationalisme. I det afsluttende kapitel forsøger Nena Močnik at se »broderskab og enhed" som en regional og tilpasset form for multikulturalisme, der blev smadret af krigene i 1990'erne. EUs mere universelle multikulturalisme kræver tid at etablere, men er nødvendig på Balkan, og er værd at bruge kræfter på, konkluderer hun.

Desværre har de to redaktører ikke rigtigt kunnet skabe en helhed af bogprojektet. Det er måske også en umulig opgave i betragtning af det rige og alsidige materiale, som præsenteres i kapitlerne. Men som læser kan det være vanskeligt at få mening i kapitlernes rækkefølge. Perspektiverne bliver ikke samlet, og der savnes en samlet diskussion og syntese. Den endelige redaktion af bogen, som må være forlagets ansvar, er desværre sjusket. Af en eller anden grund er Sabrina Ramets glimrende forord trykt $\mathrm{i}$ både første og andet bind, men referencerne er kun medtaget $\mathrm{i}$ bind 2, og flere steder er der rod i dem. Sproget kan til tider være så knudret, at interessante argumenter bliver næsten uforståelige. Alligevel er det et spændende, alsidigt og vigtigt bogprojekt, som Gorana Ognjenović og Jasna Jozelić har sammenstykket og udgivet. 